\title{
MANAGEMENT OF CONSERVATION AREAS WITH PARTICIPATION OF COMMUNITIES IN MOZAMBIQUE
}

\author{
José Manuel Elija Guamba (PhD) ${ }^{*_{1}}$ 四 (iD) \\ ${ }^{* 1}$ Faculty of Economics, Eduardo Mondlane University, Center for Studies in Economics and \\ Management (CEEG), Mozambique
}

DOI: https://doi.org/10.29121/granthaalayah.v9.i1.2021.2990

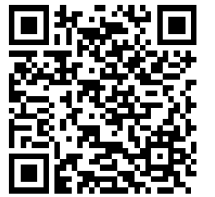

Article Type: Research Article

Article Citation: José Manuel Elija Guamba (PhD). (2021). MANAGEMENT OF CONSERVATION AREAS WITH PARTICIPATION OF COMMUNITIES IN MOZAMBIQUE. International Journal of Research GRANTHAALAYAH, 9(1), 189-201. https://doi.org/10.29121/granthaa layah.v9.i1.2021.2990

Received Date: 02 January 2021

Accepted Date: 31 January 2021

Keywords:

Conservation Areas

Communities

Participation

Social Inclusion

Natural Resources

\section{ABSTRACT}

This article discusses the challenges of managing conservation areas; in search of new institutional instruments and mechanisms that make effective conservation of biodiversity and ecosystems in protected areas. The management of conservation areas in some countries has been made from a growing demand for involvement of stakeholders and communities in decision-making in the process of managing natural resources. There are three issues surrounding the debate on participatory management of conservation areas, namely: the distribution of authority and responsibilities in the decision-making process; distribution of benefits and sustainability (ecological, social and economic).

The main reasons that justify the management of these areas with the participation of communities are: the restriction on access to resources can compromise the food security of families living there and; it is a prerequisite for communities to be able to carry out their activities, to set up joint enterprises with them, or other forms of management that make their participation effective.

The analytical approach was based on the theory of natural resource management and complemented by recent contributions from research in the areas of political sociology, poverty and the environment on the phenomenon of "participation". The local dimension, although the integrative synthesis between the natural and the human, historically and spatially located, makes essential a participatory management of conservation areas in countries such as Mozambique, because it allows the understanding and transformation of social relations that are carried out from a certain mode of production and organization established in a defined space of protection and conservation.

\section{INTRODUCTION}

Conservation areas are spaces that are created and established with the aim of preserving ecosystems and biodiversity, natural resources and cultural values of nature, through the establishment of the legal and normative framework and institutionalization of other specific instruments of management and participation. These areas are created and administered in the different territorial echelons of the public administration. At the local level, the establishment of these, has generated intense conflicts that sometimes reach great proportions, between the

(C) 2021 The Author(s). This is an open access article distributed under the terms of the Creative Commons Attribution License, which permits unrestricted use, distribution, and reproduction in any medium, provided the original author and source are credited. 
Management of Conservation Areas with Participation of Communities in Mozambique

populations living in these places and their survival depends on the use of the resources that are intended to preserve and the authorities that manage these areas.

According to Barbanti Jr. (2001), from these conflicting processes that occur in the areas of conservation, the terms "problem" and "environmental" were replaced by "conflict" and "socio-environmental". However, it is practically unanimous among scholars that environmental problems are forms of social conflicts, which involve interests, senses and ends, in the relationship between man and the environment. In other words, environmental conflicts are configured when social actors defend different logics for the management of collective assets of common use.

The control of these problems and conflicts is called management of conservation areas. The pressures are constant and quite varied, according to the possibilities of contribution to a consumer market, such as illegal trade in animals of wild fauna, introduction of exotic species or, in the case of this research, the production of coal to meet the basic needs of communities. Thus, although officially protected, it does not guarantee adequate conservation in order to ensure the maintenance of its ecosystems.

Morsello (2001), in his approach, clarifies that there are several research projects in conservation areas, but that many are directed only to biological aspects, being of fundamental importance the existence of research that addresses social aspects constituting, together, elements that support the elaboration of management plans, in joint actions involving managers, scientists and communities.

\section{OBJECTIVES}

\subsection{GENERAL OBJECTIVE}

The general objective is to provide tools for the development of appropriate policies for the protection of ecosystems and biodiversity and the adoption of an effective management system for conservation areas, with an appropriate framework and the participation of the communities living in them.

\subsection{SPECIFIC OBJECTIVES}

- Collect data, collect the documentation and available information on conservation areas in Mozambique;

- Make a diagnosis on the biological situation, biodiversity, socio-economic management systems and participation of local communities;

- Identify and analyze the various pressures, threats and opportunities that enduring conservation areas;

- Analyze Mozambique's experience of community-based natural resource management in conservation areas.

\section{METHODOLOGY}

The methodology used was exploratory research, which consisted of a bibliographic review and case study on biodiversity conservation in Mozambique. The typology of this research and empirical theoretical research, which, for Garcia and Fadel (2012) should combine the theoretical approaches with the collected information making an analysis from the observation of reality. This objective research method contributes to absorb the knowledge generated by local communities, which to some extent can be used to solve the problems identified by the social environment.

This research will combine this method with that of action research that is defined, by Thiollent, (2005), as a methodology derived from social research based empirically, conceived and carried out in association with an action or the resolution of a collective problem, and in which all those interested in the management of conservation areas are involved in a cooperative or participatory manner.

This action research method is used in Environmental Education work in conservation areas to sensitize communities of the importance of maintaining these areas.

According to Tozoni-Reis (2005), themethodology of action research in Environmental Education is centered on three "practices" that are articulated among themselves: the production ofknowledge, educational action and the participation of those involved, taking, as a starting point, an existing problem identified by communities in this 
José Manuel Elija Guamba (PhD)

research communities are no longer the subject of studies to be agents of research and producers of knowledge of their own reality.

The main feature of action research and the collective construction of knowledge, where everyone has an active voice (GONZALES, TOZONI-REIS and DINIZ, 2007). Thus, according to the theoretical basis of action research, we established the following methodological steps for this research: problem detection, interaction, generating theme, monitoring of decisions and actions; problem solving; level of consciousness.

The extensive literature review forms the foundation for theoretical research - empirical combined with action research. On this, Severino (2008, p. 122) shows that "it is the one that takes place from the available register, resulting from previous studies and research, in printed documents, such as books, articles, theses, etc. Data, information and theoretical concepts have been used in search of solutions to environmental degradation problems.

In the case of this research, it was given phase to themes related to the conservation of ecosystems and biodiversity, namely: (1) management of resources commonly used; (2) participation and citizenship (participation, representation, public space...); (3) legal framework and international conventions.

\section{LITERATURE REVIEW}

Some countries are investing in the creation of protected areas such as the strategy of conserving biodiversity, natural resources and the cultural values of humanity (Rodrigues et al., 2003). In these Conservation Areas, various levels of protection and intervention are established (Morsello, 2001). Most protected areas have been created to protect species of terrestrial fauna and flora, but they occasionally protect a considerable number of bodies of water, which makes them of great importance for aquatic species (Agostinho et al., 2005).

These spaces are separated in some parts of the territory and limited the use of land and occupation, as well as the use of their resources. Protected areas are no longer seen as fenced areas for development, but rather for the maintenance of flora and fauna species to improve the water cycle and its rainfall regime, avoid erosive processes and silting up rivers, as well as other aspects that influence quality of life.

The implementation of protected areas has faced major challenges. The causes of these areas result from the way these areas were established, with the dislodging of the populations living in these areas, the restrictions of the use of their resources, without involvement or consultation of the leaders of the communities, which resulted in social and cultural conflicts in some cases without alternatives of survival.

Man's pressure on nature has increased over time, in a dimension that accompanies economic growth and technological innovations. Today, scientific research on environmental problems has been showing frightening results about the future of the planet we live in. The main environmental problems resulting from these researches are: global warming, the destruction of the ozone layer, reduced availability of clean water, destruction of biodiversity, among others.

Economists are increasingly concerned about research on environmental problems, the search for new paradigms that can generate alternatives for managing this natural resource by looking not only at economic growth but also at encouraging the reduction of environmental degradation and improving the conditions of the well-being of populations.

Thus, the management of natural resources, encounters 3 major challenges, namely:

- The search for viable solutions to the growing problems of environmental degradation and for the sustainable management of common resources;

- The adoption of appropriate policies and management systems for the use of natural resources on a large scale;

- Find property rights systems suitable for the sustainable use of natural resources.

The answer to these questions was found, in the empirical analysis of the forms of cooperation of communities for the benefit of common goods, by Elinor Ostrom in his work " Common Pool Resource (CPR)', distinguished with the Nobel Prize in Economics in 2009.

Ostrom's theory provides evidence on the rules and mechanisms that discipline the exploitation of common natural resources by its users. The author designs a new paradigm for the management of common resources, and the implementation mechanisms that sustain cooperation in human societies. The assumption of their theory and 
Management of Conservation Areas with Participation of Communities in Mozambique

that local communities do alone, an efficient management of resources than when they are forced to follow rules imposed by the authorities. The way to arrive at the resolution of conflicts that emerge in the management of resources of common use and through organization and cooperation between individuals and institutions with interest in the use of these resources in a sustainable way; respecting the biota's load capacity and the time of its restoration.

This theory shows the principles and rules that can manage collective property, avoiding overexploitation of resources, one of the consequences referred to by Garret Hardin in his work ("The Tragedy of the Commons") with regard to the management of common resources. Ostrom's theory comes in a different theoretical field from Hardin, who maintained that users of a common good are held hostage in a system that as the degradation of resources, on which they depend for their survival, the consequence will be their exhaustion, thus showing the inability of their management by communities. On the one hand, population growth, which had resulted in increased consumption of natural resources, on the other hand the way communities organize themselves to extract these same resources. In this analysis the author suggests only two forms of organization for common resource management: statecentralized system and private property.

In Ostrom's theory of the management of common resources, he does not ignore the hypothesis of the tragedy of the commons, but on the basis of practical cases studied by him, he observed that for thousands of years, human communities organized themselves to manage common resources and did so in a sustainable way.

The lessons that can be drawn from Ostrom's empirical studies on the management of common resources, and that there are alternative solutions for the efficient management of common resources, that is to say that there are alternatives to Hardin's fatalism. According to the author, both state and private property are subject to failure in some circumstances (Ostrom et al, 1999). Success in managing common resources requires effective governance of resources; which can be managed by small groups of users, which integrate according to common rules, respected and accepted by all members of the group, involving institutions at different scales.

Common natural resources are indispensable for all and are a source of income or productive means, and are necessary to meet human needs and provide the well-being of communities give the importance of management through an efficient and sustainable process.

There are several conceptions about the issue of the participation of local communities in the process of natural resource management. In this sense, we can find several conceptions of participation in the management of common resources. For Avelar (2004).

"Participation is a Latin word whose origin dates back to the 15th century. It means "to take part in", to share, to be associated with feeling or thought. Understood succinctly, it is the action of individuals and groups with the aim of influencing the political process. Broadly speaking, 'participation is the action that takes place in solidarity with others within the state or of a class, with the aim of modifying or preserving the structure (and therefore values) of a system of dominant interests' (Pizzorno, 1966)" (Avelar, 2004: 3).

For Sachs (1986), the indicators of participation are: the power of initiative gained by the community; space for real local experiences; the degree of symmetry in civil society's relations with different levels of government and market forces; existing mechanisms for agreements and conflict resolution and; the nature of the planning process. Arnstein (2002) created the "Citizen Participation Ladder", which graduates participation in eight levels (manipulation, therapy, information, consultation, pacification, partnership, delegation of power and citizen control). Pimbert, M. and Pretty, J., (2000), in turn, created the "Typology of participation", graduating it into seven types (passive participation, participation as information extraction, participation by consultation, participation by material incentives, functional participation, interactive participation and self-mobilization).

For Gohn (2001), it is not the Community committee itself that informs us about its nature, but rather the process in which it is inserted:

"The Community committees could be both valuable tools for the establishment of democratic and participatory management, characterised by new patterns of interaction between government and society around sectoral social policies, and may also be formal bureaucratic structures and/or simple links for the transmission of social policies drawn up by summits, mere structures for transferring resources to the community, with the burden of administering them; or instruments for accommodation of conflicts and integration of individuals in previously defined schemes." Gohn (2001).

"The experiences of "Community Conservation" carried out in Southern Africa embrace a wide variety of orientations, starting from forms of passive participation, where communities have limited control over the decisionmaking phases, for a full and direct participation in resource management, defined active participation. Between 
José Manuel Elija Guamba (PhD)

these two extremes there are several combinations, which stimulated discussion in the scientific context, as well as the identification of various classifications, which focused on different aspects, including the level of participation, the ownership regime or the participatory or contractual approach." (Belloti, 2012)

The acceptance of conservation projects is divided between a population that finds there an opportunity for a better life and a population that questions the fact that it is forced to change its life, eventually breaking with traditions relevant to its emotional, social and religious balance.

"Another key issue to be taken into account in convincing local people to join the project may be that wildlife can be potentially more competitive than other forms of land use, particularly in dry savannas with little potential for agriculture or grazing for livestock." (Pinto \& Cardoso, 2012)

It is in this idea of change that there is greater adherence to conservation projects, especially with the possibility of being able to obtain a job in the various activities of the conservation area. A widespread ambition and seen as a means to have a more unobstructed life.

"... Rural populations must be provided with appropriate tools to enable them to take the reins of conservation as legitimate owners of their territory, while valuing traditional knowledge and knowledge, which for centuries have regulated the symbiotic relationship between man and nature." (Belloti, 2012)

The destruction of forests deprives people not only of wood, medicine, etc. but also of reliable freshwater reservoirs, for example, increasing the risk of flooding. The destruction of insects can lead to crop failure scum of crops that depend on their pollination. The extermination of insect pest enemies can end with the pest control services of an ecosystem and often leads to a major outbreak of pests. The extinction of underground organisms can destroy soil fertility. Examples can be multiplied (Ehrlich, 1997).

Tropical forest plants can be useful for modern agriculture in three different ways: as a source of new plantations that can be grown; as a source for breeding improved plant varieties; and as a source of new biodegradable pesticides. (Plotkin, 1997). The properties of biological diversity imply great resilience for ecosystems and organisms, and is described as a benefit arising from the services of biosphere ecosystems.

In the face of increasing human pressure on the environment, all these benefits should strongly encourage nature conservation actions. The most precious and intangible value of biodiversity is the fact that it results from the long evolution of life on Earth, exclusive in the solar system, due to the accumulation of processes triggered by life itself (Wilson, 1994).

\section{TROPICAL DIVERSITY}

Tropical zones concentrate the highest rates of biological diversity (Wilson, 1997). Some theories try to explain the reasons for this phenomenon: the hypotheses of time, climate stability, spatial heterogeneity, competition and predation are some of the most accepted theories (Pinto-Coelho, 2000, apud Horowitz, 2003). The hypothesis of time states that, as tropical environments are older than arctic and temperate environments, their species had more time to evolve and diversify (Ricklefs, 1996). The hypothesis of climate stability says that tropical regions have been less disturbed by the glacial periods that have followed in the last 65 million years. The continuous droughts of the Ice Age restricted species to geographical isolation by increasing species variety (Ricklefs, 1996).

Spatial heterogeneity establishes that very varied habitats favor increased diversity, since they offer greater combinations of micro habitats and ecological niches. The hypothesis of the competition argues that in the tropics there is greater competition between organisms, which induces their increasing specialization in the use of available resources (Pinto-Coelho, 2000 apud Horowtz, 2003; Ricklefs, 1996).

Wilson (1997) cites examples about the diversity of species in tropical ecosystems that express the richness of these areas: in a single legume plant in the Tambopata Reserve in Peru, 43 ant species belonging to 26 genera were found, the same as the entire ant fauna of the British Isles (Wilson, 1997); in the sum of ten hectares randomly selected in a Malaysian forest, 700 tree species were identified, the same amount of species that occurs throughout North America (Wilson, 1997).

Mozambique located on the eastern coast of Africa, is part of countries with a diversity of species of tropical ecosystems and has ecosystems of great ecological, social and economic value. It has several areas considered of great importance from the biological point of view, called "Hotspots" of Biological Diversity and with a biodiversity of natural resources (IUCN 2005). 
The characterization of ecosystems was based on the categorization system developed by the World Wildlife Foundation (WWF) called eco regions, with three main categories, namely: (i) eco terrestrial regions, (ii) eco coastal and marine regions and (iii) eco regions of freshwater systems.

Thus, there are 3470 vertebrate species in Mozambique, namely 271 species of mammals, 816 of birds, 280 of reptiles, 84 of amphibians and 2019 of fish. 234 are endemic or almost endemic species and 503 vertebrate species are threatened with extinction and protected by national and international law. In this conservation process, 20 vertebrate species were introduced into the conservation areas.

The regions with high biodiversity and areas rich in endemic, threatened and protected species in Mozambique are:

1) The Region of Serra da Gorongosa - Rift Valley - Marromeu Complex in the Provinces of Sofala and Manica;

2) The Rugged Region of Chimanimani In Manica Province;

3) The Libombos Mountains in Gaza And Maputo Provinces;

4) The Coast of Inhambane, Gaza And Maputo Provinces;

5) The Centre Of Endemism in Maputaland To the South of Maputo Province;

6) The Inselbergs Mountain Range in The Provinces of Zambezia And Nampula,

7) Including Mount Chiperone And Mount Namúli;

8) The Quirimbas Archipelago in Cabo Delgado Province;

9) The Niassa Special Reserve in Niassa Province.

Mozambique is recognized as a resource-rich country with regions rich in biodiversity and endemic species, where it has established conservation areas; and considered to be able to emerge from poverty, develop, and grow from an economic point of view at the level of the most prosperous in the region and the African continent.

The Conservation Areas occupy about 18.57 million hectares, which correspond to about $25 \%$ of the national territory, and include 7 National Parks, 9 National Reserves, 20 Official Coutadas, 3 community conservation areas and 50 Bravio Farms.

Given the importance that conservation areas have, not only in the conservation of biodiversity, but also for the socio-economic development of the country, especially of local communities living in rural areas, the Government has established the National Administration of Conservation Areas (ANAC) to respond to the challenges that arise in managing these areas and the new dynamics of the need for participation and inclusion of the communities that live there and contribute to the generation of revenues aimed at sustaining the biodiversity conservation and improving the well-being of communities.

The social relations present in the territory of conservation areas are relevant for research and analysis of the human sciences, but it has less prominence in the list of research conducted in these areas. In this case it is possible to carry out surveys of information on the relationship of these areas with the local population, of socio-economic activities that threaten the nature and cultural aspects, often unique and characteristic of each region.

The information and data disclosed show that the areas of conservation, through the body that administers them, are instruments, which has the potential to safeguard the natural heritage and serve for the scientific development of topics relevant to natural, socio-economic, socio-environmental and political aspects.

Research and research institutions play an important role in scientific development in conservation areas, and their relationships with local populations and communities. Discussions on socio-economic development, enhancement of biodiversity, biomes, local culture and encouraging environmental sustainability practices are topics that can be investigated in research, disseminated in seminars and conferences; but also, in board meetings, as proposals for improvements in the management and environmental socio-environmental management of conservation areas.

\section{PARTICIPATION OF LOCAL COMMUNITIES IN BIODIVERSITY CONSERVATION}

The characterization of Mozambique's ecosystems is not systematized, and there is a need for the definition of criteria for their categorization and comprehensive studies on their specific ecological processes, as well as information on their distribution and geographical extent. Existing bibliographic references that meet a more systematic description of the country's ecosystems refer to regional or mainland work or to specific work on 
José Manuel Elija Guamba (PhD)

geographically circumscribed areas, resulting in a generalized description or lacking appropriate national coverage. In this strategy paper, a system of categorization designated - Eco regions- under development by the World Wild Fundation (WWF) was adopted as support for the description of the country's ecosystems.

The criteria for their characterization reflect biogeographic affinities in recognition of hierarchical factors such as: (i) the climate at regional level, (ii) physiognomic characteristics and specificity of biological resources such as vegetation, flora and animal population, (iii) geological and soil properties and, (iv) various factors that define differently the composition, structure and functioning of certain biological processes in certain regions. Eco regions in Mozambique are regrouped into three categories, namely: (i) Eco continental plate regions, (ii) Eco coastal and marine regions and (iii) Eco regions of freshwater systems.

\section{RESULTS ANALYSIS}

From an environmental point of view, African countries are commonly defined as a world of contrasts, as it is possible to find various types of ecosystems, each characterized by different landscape and heritage elements. However, in any of these areas live human communities that establish diversified relationships with space and as natural resources, fauna and flora. However, populations establish direct contact with the environment, on which they depend to survive and produce, marked by permanence and continuity without systemic planning.

In Mozambique, the close relationship between populations and the environment shows a high trend for households living in poverty, with a particular focus on rural areas. In view of the productive incapacity and difficulty, derived in many cases from the negative effects of climate change, communities have perpetuated the practice of collecting and extracting natural resources for consumption, sale or transformation, significantly affecting conservation areas. The reasons for a high value relate to the proliferation of practices of stealth cad, unregulated fishing, cutting wood for fuel, uncontrolled burning.

Given the sociocultural characteristics that define the population of African countries, including Mozambique, distinguishing them from that of any other region of the world, the principles inherent to participatory management of conservation areas and the involvement of local groups in the actions promoted arise spontaneously, valuing the accountability of target groups and awareness of the identification of alternatives to some traditional practices.

The identification of alternative forms of planning of conservation areas involving basic communities implies the adoption of co-management systems among local populations, civil society organizations such as nongovernmental organizations, associations, cooperatives, municipalities and other decentralized government entities.

In this perspective, community conservation areas are now more flexible in decision-making regarding ecosystem modification, the conservation of biological diversity, the creation of specific services and the adaptation of cultural values and patterns that underpin community life, giving them identity systems and reinforcing the sense of belonging.

In Mozambique, some experiences can be referenced, such as the legal framework that regulates the organization and functioning of conservation areas that enshrines these principles of participatory management. However, major challenges remain for the effective compliance of this legislation, which relate to the difficulty of managing commonly used resources (Hardin, 1968); and also conflicts that result from the need to withdraw populations living within conservation areas that have generated man-fauna conflict often with human losses, among others.

What differentiates these concepts is above all the degree of participation of communities and their real influence on project management, which tends to be relatively incipient. An idea that results from an inclusive discourse for participation and sharing, but which tends to be diluted in the implementation of the measures, clearly favouring the protection of ecosystems and biodiversity. However, there is an undeniable increasing attention of policy makers to the problem of conservation and its coexistence with local communities, as well as their willingness to rebuild some protected areas.

Mozambique, as a signatory to the Convention on Biological Diversity, has committed to promoting the development of conservation areas through participatory processes of planning, administration and management of protected areas. The participatory management methodology creates a favourable environment for greater efficiency and effectiveness in the activities that are carried out for the conservation of biological diversity and integration of local communities, the private sector and other civil society actors engaged in nature conservation. 
Management of Conservation Areas with Participation of Communities in Mozambique

This participatory management methodology is guided by some principles that address issues of ownership of resources, conservation planning, use of resources, aspects associated with the presence of communities in the interior or surrounding protected areas, administration and management, promotion of investments, treatment of the private sector and participation of other actors. The principles that guide the conservation, restoration and management of protected areas in the legal framework in Mozambique are:

\section{- Ownership of Natural Resources}

Natural resources in soil and subsoil, inland waters, territorial sea, continental shelf and the exclusive economic zone are owned by the State;

\section{- Sustainable Development}

Development should be based on environmental management that meets the needs of the present generation without compromising the balance of the environment, allowing future generations to also meet their needs;

\section{- Sustainable Exploitation of Natural Resources}

Forest and faunistic resources should be used rationally and controlled, through the application of scientific and technical knowledge, with a view to achieving resource conservation objectives for present and future generations;

\section{- Integration of Local and Private Sector Communities}

Policies for economic and social development and biodiversity preservation should involve local communities, the private sector and civil society in general, with the aim of achieving sustainable development in the present without compromise future generations;

\section{- Establishment of Partnerships and International Cooperation}

Concertation of harmonious solutions with international organizations is promoted conservation and management of forest and wildlife resources.

The so-called Community Based Natural Resources Management (CBNRM) management model distinguishes three forms of community participation in conservation projects, namely: Protected Area Outreach, Co-Management (Collaborative Management) and Community Based Natural Resources Management (CBNRM). (Cencini, 2004)

The CBNRM approach in Mozambique began in the 1990s in the Tchuma Tchato project, inspired by the experiences of the Campfire Programme projects - in Zimbabwe and the Administrative Management Design Programme (ADMADE) - in Zambia (Nhantumbo, Chonguca and Anstey 2003 and Jones, 2002). The Tchuma Tchato project in Tete Province comes in an attempt to resolve the conflict between the safari operator who has a bravio farm concession and local communities. The project consisted of the involvement of communities living in the concession area, in the management of natural resources and obtaining benefits that would result from the revenues generated by the operator in the exploitation of natural resources.

The project was later influenced by the development of CBRNM policies that provided practical experiences for planners and policymakers. Currently the policies and the legal framework that regulates the organization and functioning of conservation areas incorporates a significant part of the results of the implementation of CBRNM, going beyond the limits of the approach of the Tchuma Tchato project.

The implementation of CBRNM aimed to achieve the social objective of the policy by promoting practices of sustainable use, generation and distribution of the resulting benefits and involvement of the Community in the effective management of natural resources, as well as the framework of this objective in the legal framework (Nhantumbo, Chonguica and Anstey, 2003).

Legislation on conservation areas provides, among other things, for participatory management of natural resources and the possibility of granting the management of fauna and flora to local communities and the private sector. This process is bringing significant improvements in the conservation and sustainable use of natural resources, with benefits for communities.

This process leads to the need to develop a management plan that defines the main rules for the use of natural resources. This plan should be developed through a participatory process involving different actors in the area (e.g. women, coal producers, traditional leaders, fishermen, farmers, traders, students, teachers, local government, local 
José Manuel Elija Guamba (PhD)

authorities, private sector, etc.). This plan is summarized in a document called a management agreement that must be approved by local community interest groups in the use of natural resources and local government authorities.

The Government, in wanting to insert all actors in the decision-making on public policies, through the institutionalization of mechanisms of participation, must be willing to also to establish less unequal relationships. In this sense, Santos Júnior (2001, p.105) points out that:

[...] social inequalities generate situations of power asymmetries and inequality of social participation conditions. [...] However, despite the limitations, local governments can intervene to expand citizens' access to social and political rights and thereby enable groups in situations of social disadvantage.

It is also necessary to highlight, in this case, that, instead of strengthening emancipatory relations, participatory processes have often been used to strengthen unequal relations, through the use of energy by actors with greater economic and political power, as formulated by Santos (2002, p.74):

"[...] the public space and the debates and social demands that constitute, can be co-opted by hegemonic interests and actors to, on the basis of legitimate social exclusion and repression of difference." Still according to with the author, the institutionalization of participation can bring other risks, which distort its meaning, as a process against hegemonic. [...] Perversion can occur in many other ways: by bureaucratising participation, by reintroduction of clientelism in new forms, by party instrumentalization, by the exclusion of subordinate interests through the silencing or manipulation of participatory institutions (SANTOS, 2002, p.75).

Despite the importance of institutionalizing the participatory management process, as a way of ensuring the right to participation of the population, hegemonic interests can, through the State itself, appropriate these institutions of participation, contributing to the strengthening of an even more asymmetric relationship.

In this context, in Mozambique, the stimulus to participation involves not only the establishment of the legal framework, but also the existence of effective mechanisms for the empowerment of communities and their leaders, without simplifying the demands and contempt of local knowledge that is always present in the communities. In the case of rural communities living in conservation areas in socio-economic poverty, some of the choices are not accessible, given the level of need they go through. In this sense, even if there are moments of definition or consultation with the population, these may not constitute a choice.

The criteria that guide the choices may be the most diverse. According to Sen (2000), social choices are permeated by factors such as prior access to information, opportunities for discussion with other actors and the construction of social values arising from the interaction of all actors involved. The vision of freedom defended by the author involves "[...] both the processes that allow the freedom of action and decisions and the real opportunities that people have, given their personal and social circumstances" (SEN, 2000, p.31).

However, the participatory capacities of the population do not depend only on the possibility of choices. The conditions in which these choices are established end up interfering with them, in the case of a poor population, it is reflected in concrete limits.

The choices depend, in part, on the information base that one has and, therefore, to have greater possibilities of choices there should be no asymmetry of information. As SEN argues, "[...] by expanding information on the processes and projects to be implemented, consistent and consistent criteria for social and economic evaluation can be reached" (SEN, 2000, p.288).

The use of technical language often constitutes a barrier to content assimilation and ends up reinforcing established power relations. The type of information passed on can also help strengthen decisions made in other spheres and not necessarily contribute to a choice. That is, in an asymmetric relationship, who

you can choose what to disclose, so that such information serves to legitimize your prior definitions.

For example, the complexity of the Gorongosa National Park conservation project in Mozambique includes the expectations of the ecological system restoration program versus the expectations of a local population dependent on the use of natural resources for their survival, and its success will be to find a collective ethics that is a moral in favor of mutual understanding that should generate mutual benefits. Thus, the ethical and moral sense, based on a natural awareness of otherness, intensifies in the concept of the useful (Rodrigues, 2002).

A utility that is required in the face of widespread recognition of damage caused by fractured planning. The current information network projects a holistic awareness that is established through an idea of sharing benefits with local communities and continuity in ecosystem influences, resulting from participatory management involving local communities living in this conservation area. 
Management of Conservation Areas with Participation of Communities in Mozambique

"A holistic evolutionary approach is used in the Gorongosa thesis III which emphasis is on the salient reciprocal relations and kinetic succession of land surfaces and biotic communities, influenced by landscape processes and prime mover components." (Tinley, 1977)

It will be possible to question the ability of man to organize himself for a more effective management of the territory, taking into account the past of a history that is manifestly predatory, as well as the current divergences and complexity of motivations in his actions. The answer is perhaps no longer only a morality of the problem but in the fact that it is a growing and widespread problem, which can transform the common idea of a utopian demand into an emergency consciousness capable of mobilizing the world.

\section{CONCLUSION}

The growth of human communities and the increased demand for natural resources has triggered a sharp increase in the ecological footprint of human beings on earth. The fact that many commonly used resource management strategies at local level, are planned by institutions and central authorities, away from local reality and with little knowledge of local conditions, results in the failure of measures and the result is often the degradation of natural resources and biodiversity.

In this context, scientific research and the use of technologies can play a fundamental role, assisting in informed decision-making and improving the identification and conservation of natural resources, allowing their sustainable management.

The territory, as a space of interaction between the natural and the human, historically and spatially located, becomes essential a participatory management of conservation areas in countries such as Mozambique, allowing greater understanding and transformation of social relations.

Mozambique's experience on the application of the 'community-based natural resource management' model in conservation areas shows that the fundamental conditions for the success of this model are:

1) an appropriate political, legal and institutional environment;

2) Greater social cohesion in communities;

3) Control over resources with higher substantial value (biodiversity);

4) access by local communities to information on natural resources, management and markets;

5) fair sharing of the benefits of conservation of natural resources with communities and other stakeholders.

An evaluation of the programs implemented in conservation areas reveals positive trends in community participation, such as: (1) Greater interest of rural communities in investing for the future in exchange for immediate benefits;(2) Existence of some cases of sharing benefits of conservation areas with communities and other stakeholders; (3) Expanded diversification and participation of communities; (3) Positive changes in communities, attitudes, level of participation in resource management, knowledge about resources and dissemination of good practices; (4) Need for continued support in the areas of training, insum, technical assistance and funding.

The macro-level analysis shows that the acceptance of Community initiatives counterbalanced by inconsistencies and or arbitrariness in the support provided by projects (community-based natural resource management - CBNRM) and by the weakness of their capacity and institutional fragility of the Community committees for the management of natural resources. A comparative study carried out in 2007 of the implementation of this community-based natural resource management model - CBNRM, in the policy and legal framework areas that govern conservation area management processes in the countries of the region, namely: Botswana, Malawi, Mozambique, Namibia, Zambia and Zimbabwe; showed positive results in community participation, benefit sharing, poverty-fighting and significant improvements in ecosystem and biodiversity conservation.

The experience of "community-based natural resource management - CBNRM" in Mozambique suggests that stakeholders' perceptions of the value of resources and the potential benefits of co-management of natural resources have received little attention from conservation area managers. Greater recognition of the value of natural resources at the level of local communities and their effective participation from timely information sharing, the development of alternative income generation and employment activities, and a fundamental condition for efficient management of natural resources. 
José Manuel Elija Guamba (PhD)

The sense of starting from social groups in situations of environmental vulnerability is to highlight the reality of the majority, democratize access to information and understand society in its multiple contradictions. By state of socio-environmental vulnerability, we understand the situation of specific groups that are: (1) to a greater degree of direct dependence on natural resources to produce, work and improve living conditions; (2) excluded from access to socially produced public goods; and (3) absent from legitimate participation in decision-making processes regarding the definition of public policies that interfere in the quality of the environment in which one lives.

In order to achieve the above-mentioned local conditions, it is important to understand the situation of education in Mozambique and its relationship with other activities that indulge or foster it, in the sense of the democratic guarantees that everyone must enjoy, as well as the whole set of basic goods and services indispensable to social welfare, in line with the balance of ecosystems that we want to be conserved.

Thus, participatory management of conservation areas is based on multidisciplinary and should take into account the five dimensions of sustainable development, namely: (i) social sustainability, (ii) economic, (iii) cultural, (iv) political and (v) spatial/geographical. The fundamental instruments of participatory management of conservation areas; are the Community Committees for the Management of Natural Resources created in the communities that live around the protected areas. The representativeness of these committees in the management bodies of each conservation unit allows their participation in decision-making and their implementation and benefits that improve the quality of life of these communities.

\section{SOURCES OF FUNDING}

This research received no specific grant from any funding agency in the public, commercial, or not-for-profit sectors.

\section{CONFLICT OF INTEREST}

The author have declared that no competing interests exist.

\section{ACKNOWLEDGMENT}

None.

\section{REFERENCES}

[1] Agostinho, A.; Thomaz, S. \& Gomes, L. (2005) Conservation of the biodiversity of Brazil's Inland Waters. Conservation Biology, vol. 19, no. 3, p. 646-652.

[2] Arnstein, S. (2002) Uma Escada de Participação Cidadã. In: Revista Participe. Rio de Janeiro: Associação Brasileira de Promoção da Participação.

[3] Avelar, L. (2004) Participação Política. In: Avelar, L. E Cintra, A.C. Sistema político brasileiro: uma introdução. São Paulo: Editora Unesp.

[4] Barbatini JR, O. (2001) Conflitos Socioambientais: Teoria e Prática. In ANPPAS, Indaiatuba, São Paulo.

[5] Belotti, S. (2012) Meio Ambiente e Turismo Sustentável em Moçambique: Organização Territorial e Conhecimentos Culturais no Parque Nacional do Zinave, Università degli Studi di Bergamo/Università degli Studi di Napoli “L’Orientale”, IICT - Instituto de Investigação Cientifica Tropical, Lisboa.

[6] Bensuasan, N. (2006) Conservação da Biodiversidade em Áreas Protegidas. Rio de Janeiro, Editora FGV.

[7] Cencini, C. (2004) Vivere con la natura. Conversazione e comunità locali in Africa sub sahariana, Bologna, Patron.

[8] Collar, N.; Stuart, S. (1988) Key forests for threatened birds in Africa. International Council for birds Preservation: Cambridge.

[9] Cronon, W. (1995) The Trouble with Wilderness; or, Getting Back to the Wrong Nature. In: CRONON, William (Edited by). Uncommon Ground: Rethinking the Human Place in Nature. New York: Norton, 1996, pp. 69-90.

[10] Diamond, J. (2005) Armas, Germes e Aço: os Destinos das Sociedades Humana. Rio de Janeiro, Record. 
Management of Conservation Areas with Participation of Communities in Mozambique

[11] Dutton, T.; Dutton, E. (1975). Reconhecimento preliminar das montanhas de Chimanimani e zonas adjacentes com vista à criação duma área de conservação. Anais do Serviços do Veterinária de Moçambique 20/21: 123203.

[12] Ehrlich, P. (1997) A Perda da Diversidade - Causas e Consequências. In: Biodiversidade. Wilson, Edward (org.) (1997). São Paulo: Editora Nova Fronteira.

[13] Garcia, R.; Fadel, B. (2012) A Percepção do indivíduo na gestão do conhecimento organizacional: estudo teórico-empírico das influências da interferência nos fluxos informacionais na criação de conhecimento e tomada de decisão. Disponível em:<http://www.facet.br/novo/3fem/Encontro/Arquivos/Regis_Garcia_e_Barbara.pdf>. Acesso em: 04 out. 2012.

[14] Gohn, M. (2001) Conselhos Gestores e Participação Sociopolítica. São Paulo: Cortez, 2001.

[15] Gonzales, L.; Tozoni-Reis, M.; Diniz, R. (2007) Educação Ambiental na

[16] Comunidade: uma Proposta de Pesquisa-Acção. Rev. Eletrônica Mestr. Educ. Ambient., Rio Grande, v. 18.

[17] Hardin, G. (1968) The Tragedy of the Commons. In: Science, 162.

[18] Hess, G.; Fischer, R. (2001) Communicating Clearly About Conservation Corridors. Landscape and Urban Planning, 55 p.195-208.

[19] Hess, C.; Ostrom, (2007) E. Understanding Knowledge as a Commons: From Theory to Practice. Cambridge, Massachusetts. MIT Press.

[20] Horowitz, C. (2003) A Sustentabilidade da Biodiversidade em Unidades de Conservação de Proteção Integral: Parque Nacional de Brasília. 2003. 329 p.

[21] _ IUCN. (1998) Economic Values of Protected Areas: Guidelines for Protected Area Managers. IUCN Gland, Switzerland.

[22] _ _ IUCN (International Union for Conservation of Nature). (2005). IUCN Red list of threatened species. http:// iucnredlist.org.

[23] Jones, B. (2002). Evaluation Report. Tchuma Tchato Programme, Tete Province, Mozambique. Provincial Directorate of Agriculture and Rural Development. Tete.

[24]

[25] Jones, B. (2007) Synthesis of the CBNRM Policy and Legislation in Botswana, Malawi, Mozambique, Namibia, Zambia and Zimbabwe. WWF - SARPO Occasional Paper Number 16 October 2007. WWF Regional CBNRM Programme Number 9F0751 WWF - SARPO 10 Lanark Road Belgravia. Harare-Zimbabwe.

[26] Laville, C.; Dionne, J. (1999) A construção do saber: manual de metodologia da pesquisa em ciências humanas. Belo Horizonte: UFMG.

[27] Leveque, C. (1999) A Biodiversidade. Bauru/SP: EDUSP.

[28] McNeely, J. (1994) Critical Issues in the Implementation of the Convention Biological Diversity. In: Krattiger Anattole F. et al. Wedening Perspective on Bioiversit. Switzerland IUCN/ International Academy of the Environment. Geneva.

[29] Michael F.; Victorino A.; Luís A. \& Filipa S. (2004) 'Checklist' e Centros de Diversidade de Vertebrados em Moçambique. Departamento de Engenharia Florestal, Universidade Eduardo Mondlane, Maputo.

[30] _ MICOA. (2003). Estratégia e Áreas de Acção para a Conservação da Diversidade Biológica em Moçambique. Ministério para a Coordenação da Acção Ambiental (MICOA), Maputo

[31] Mooney, H.; Bullock, S.; \& Medina, E. (1995) Introduction. pp. 1-8. In: mooney, H. s. h. Bullock S. \& Medina, E. (eds.), Dry tropical forests, Cambridge University press, Cambridge.

[32] Morcello, C. (2001) Áreas Protegidas Públicas e Privadas: Seleção e Maneio. São Paulo: Fapesp, Annablume.

[33] Nhantumbo, I., Chonguica, E. \& Anstey, S. 2003. Community Based natural Resources Management in Mozambique: The challenges of sustainability. Chapter prepared for SASUSG book Vol II.

[34] Palmer, R.; Finaly, V. (2003) Faith in Conservation: New Approaches to Religions and Environment. World Bank, Washington D.C.

[35] Pinto, A..; Cardoso, L. (2012) Quando os elefantes lutam e a erva sofre estratégias de desenvolvimento e conservação no parque nacional do Limpopo em Moçambique. IICT - Instituto de Investigação Cientifica Tropical. Lisboa.

[36] Pimbert, M.; Pretty, (2000) J. Parques, Comunidades e Profissionais: Incluindo "Participação" no Manejo de Areas Protegidas. In: Diegues, A.C. Etnoconservação: Novos rumos para a proteção da natureza nos trópricos. São Paulo: Hucitec. 
[37] Pizzorno, A. Condizioni della participazione política. In: Pizzorno, A. Le radici della politica assoluta. Milano, Feltrinell, 1966.

[38] Plotkin, M. (1997) A Perspectiva Para os Novos Produtos Agrícolas e Industriais nos Trópicos. In: Wilson, E. O. (Org); Biodiversidade - Rio de Janeiro: Nova Fronteira, 1997.

[39] Ostrom, Elinor (1999): Design principles and threats to sustainable organizations that manage common. Center for the Study of Institutions, Population, and Environmental Change, Workshop in Political Theory and Policy Analysis, Indiana University.

[40] Ostrom et al (1999): Revisiting the Commons: Local Lessons, Global Challenges, Science, Vol. 284. no. 5412, pp. $278-282$.

[41] Ricklefs, R. (1996) A Economia da Natureza. Rio de Janeiro, Editora Guanabara Koogan, $3^{\mathrm{a}}$ ed.

[42] Rodrigues, A.; Andelman, S.; Bakarr, M.; Boitani, L.; Brooks, T.; Cowling, R.; Xie, Y. (2003). Global Gap Analysis: towards a representative network of protected areas. Advances in Applied Biodiversity Science 5. Washington DC: Conservation International.

[43] Rodrigues, A. (2002) Parcerias: Sustentabilidade e Conflitos nos Modelos de Gestão Envolvendo as Comunidades, o Sector Privado e os Governos Locais. In: Comunidades e Maneio dos Recursos Naturais. Memórias da 2 ${ }^{a}$ Conferência Nacional sobre Maneio Comunitário dos Recursos Naturais, Maio de 2001, eds. E. Filimão \& H. Massango, pp. 37 - 63. Maputo, Moçambique: UICN, DNFFB e FAO.

[44] Sachs, I. Ecodesenvolvimento. São Paulo: Vértice, 1986.

[45] Santos Jr., O. (2001) Democracia e Governo Local: dilemas da reforma urbana municipal no Brasil. Rio de Janeiro: Revan.

[46] Santos, M. (2002) A Natureza do espaço. Técnica e tempo. Razão e emoção. São Paulo: Edusp.

[47] Sen. A. (2000) Desenvolvimento como liberdade. São Paulo: Companhia de Letras.

[48] Severino, A. (2008) Metodologia do trabalho científico. ed. São Paulo: Cortez, 007.

[49] Silva, C. (1999) Desenvolvimento de Metodologia para análise da adequação e enquadramento de categorias de manejo de unidades de conservação. Dissertação de Mestrado. Rio Claro: UNESP/CEA.

[50] Thiollet, M. Metodologia da Pesquisa-Acção. 14. ed. São Paulo: Cortez, 2005.

[51] Tinley, K. (1977) Framework of the Gorongosa Ecosystem, Mocambique. D. Sc. thesis. University of Pretoria, South Africa.

[52] Tozoni-Reis, M. (2005) Pesquisa-Acção: Compartilhando Saberes. Pesquisa e Acção Educativa Ambiental. In: FERRARO JR., L.A. (Org.). Encontros e caminhos: formação de educadoras (es) ambientais e coletivo educadores. Brasília: Ministério do Meio Ambiente.

[53] Van Wyk, A. (1996) Biodiversity of the Maputaland Centre. In: van der Maesen, L.J.G. et al. (eds.), The Biodiversity of African Plants: 198-207.

[54] Whittaker, R. (1998) Island Biogeography - Ecology, Evolution, and Conservation. Oxford University Press.

[55] Werger, M. (1978) Biogeography and ecology of Southern Africa. Vol 1 e Vol 2. Dr W. Junk bv Publishers, Hague.

[56] Wilson, E. (2013) O Renascimento da Gorongosa. in National Geographic, 125o aniversário - Os Novos Exploradores. Junho 2013. Vol.13, no147.

[57] Wilson, E. (1994) Diversidade da Vida. São Paulo: Companhia das Letras.

[58] Wilson, (1997) E. Biodiversidade. Rio de Janeiro: Nova Fronteira, 1997. 182

[59] ___ World Resources Institute (WRI). A Estratégia Global da Biodiversidade: Diretrizes de Acção Para Estudar, Salvar e Usar de Maneira Sustentável e Justa a Riqueza Biótica da Terra. WRI: IUCN; s.l.1992. 